\title{
ANALISIS PENGARUH MEDIA PEMBELAJARAN BERBASIS VIDEO PADA PEMBELAJARAN FISIKA
}

\author{
Muhammad Haidir, Farida Farkha, Diah Mulhayatiah \\ Program Studi Pendidikan Fisika, UIN Sunan Gunung Djati Bandung \\ Email: muhammadhaidirfisika@gmail.com
}

Diterima: 26 November 2020. Direvisi: 18 Maret 2021. Disetujui: 20 Maret 2021.

\begin{abstract}
Abstrak
Penelitian ini adalah penelitian studi kepustakaan (library research) yang bertujuan untuk mengetahui pengaruh media pembelajaran berbasis video untuk meningkatkan pemahaman siswa pada konsep fisika. Teknik analisis data yang digunakan dalam penelitian ini adalah metode analisis isi teori yang dikumpulkan (content analysis). Analisis ini digunakan untuk mendapatkan inferensi yang valid dan dapat diteliti ulang berdasarkan konteksnya. Analisis ini akan dilakuakan proses memilih, membandingkan, menggabungkan dan memilih berbagai pengertian hingga ditemukan yang relevan. Dari Hasil analisis artikel maka diperoleh hasil penelitian yaitu media pembelajaran berbasis video sangat layak digunakan dalam proses pembelajaran dan media pembelajaran berbasis video juga sangat diminati peserta didik serta media pembelajaran berbasis video dapat mempengaruhi aktifitas pembelajaran peserta didik.
\end{abstract}

Kata Kunci: Media Pembelajaran, Studi Literatur, Pemahaman Konsep Fisika.

\begin{abstract}
This research is a library research which aims to determine the effect of video-based learning media to improve students' understanding of the concept of physics. The data analysis technique used in this study is a content analysis method. This analysis is used to obtain valid inferences and can be re-examined based on the context. In this analysis, the process of selecting, comparing, combining and selecting various meanings will be carried out until they are found that are relevant. From the results of the analysis 10 articles, the results obtained are that video-based learning media is very suitable for use in the learning process and video-based learning media is also very attractive to students and video-based learning media can affect student learning activities.
\end{abstract}

Keywords: Learning Media, Literature Research, Understanding Physics Concepts.

\section{PENDAHULUAN}

Media pembelajaran merupakan alat perantara pesan dalam hal ini materi pelajaran kepada peserta didik. Pemanfaatan media pembelajaran dapat diterapkan sedapat mungkin dalam semua mata pelajaran, 
Haidir., Farkha., Mulhayatiah. - Analisis Pengaruh Media Pembelajaran...

termasuk fisika. Dengan adanya media pembelajaran diharapkan mempermudah guru menyampaikan materi pelajaran dan membantu siswa, memudahkan pemahamannya dalam memahami materi tersebut serta membuat siswa tidak jenuh menyimak materi pelajaran yang disampaikan oleh guru melalui media pembelajaran yang digunakan (Basri \& Khatimah, 2019).

Penelitian yang dilakukan oleh (Yunita \& Wijayanti, 2017) dikatakan bahwa media pembelajaran yang digunakan guru hanya berupa tampilan gambar dan penjabaran materi yang disajikan dengan program Microsoft Word. Pada penampilan media tersebut, guru hanya memberikan penjelasan materi saja sehingga menyebabkan proses pembelajaran yang berlangsung didominasi oleh guru. Selain itu, guru belum menciptakan adanya interaksi yang baik antara siswa dengan guru maupun siswa dengan siswa sehingga mengalami kesulitan untuk mengajak siswa agar terlibat aktif dalam proses pembelajaran.

Media pembelajaran yang tepat untuk mengatasi permasalahan tersebut yaitu media pembelajaran berbasis video, seperti yang dijelaskan dalam penelitian yang dilakukan oleh (Agustiningsih, 2015) penggunaan media video sebagai media tambahan dalam proses pembelajaran kurikulum 2013 pada sekolah dasar didasarkan atas alasan yaitu hasil tinjauan terhadap buku siswa dan buku guru yang di dalamnya memuat contoh media pembelajaran yang akan digunakan pada proses pembelajaran.

Contoh media yang digunakan di dalam buku siswa dan buku guru yaitu menggunakan media lingkungan dan media gambar. Media video merupakan media pembelajaran yang tidak tercantum di dalam buku siswa dan buku guru, sehingga media ini cukup menarik dan efektif jika digunakan sebagai media tambahan pada kurikulum 2013. Alasan kedua dipilihnya media video sebagai media tambahan pada kurikulum 2013 adalah hal ini sesuai dengan pendekatan yang digunakan pada kurikulum 2013 yaitu pendekatan saintifik. Sesuai dengan hasi penelitian yang dilakukan (Busyaeri, Udin, \& Zaenuddin, 2016) bahwa 
Haidir., Farkha., Mulhayatiah. - Analisis Pengaruh Media Pembelajaran...

media pembelajaran berbasis video mampu meningkatkan hasil belajar peserta didik dan media pembelajaran berbasis video sangat diminati peserta didik.

Video dalam pembelajaran fisika telah banyak dikembangkan pada materi-materi fisika,yang seluruhnya telah valid untuk digunakan sebagai media pembelajaran.Format dan jenis video dapat disusun sesuai denan kebutuhan pembelajaran fisika,contohnya sebagai media eksperimen atau praktikum (Hafizah, 2020)

Contoh media pembelajaran berbasis video ini salah satunya adalah media pembelajaran berupa Videoscribe yang merupakan multimedia berbasis komputer, berupa audiovisual dalam bentuk animasi dengan gambar dan teks bernarasi atau lebih dikenal dengan witheboard animation (Sakti, 2019). (Yudha, Asrul, \& Kamus, 2016) menyatakan bahwa keuntungan penggunaan Sparkol VideoScribe dalam pembelajaran diantaranya dapat memberikan kemudahan untuk menjelaskan pelajaran, karena software ini membantu menjelaskan materi pembelajaran dengan bantuan animasi komputer.

Video ini terdapat gerakan tangan yang seperti sedang menggambar atau menulis, jadi gambar yang biasanya ditampilkan dalam sebuah presentasi akan langsung muncul dalam slide, dalam software ini di animasikan seperti tangan sedang melukis gambar tersebut yang membuat pelajaran menjadi lebih menarik dan menyenangkan, sehingga diharapkan dapat meningkatkan kemampuan siswa dalam memahami pelajaran dengan lebih mudah, dapat menghemat waktu dan meningkatkan motivasi siswa dalam belajar. Penelitian diatas juga didukung penelitian yang dilakukan oleh (Jannah, Harijanto, \& Yushardi, 2019) tentang aplikasi nedia pembelajaran fisika berbasis Sparkol Videosribe mampu meningkatkan hasil belajar peserta didik, media pembelaajaran berbasis videoscribe cukup efektif dan mendapatkan respon dari peserta didik yang baik. Penelitian lain juga dilakukan oleh (Fauzan \& Rahdiyanta, 2017) menyatakan bahwa adanya media pembelajaran berbasis video dapat 
Haidir., Farkha., Mulhayatiah. - Analisis Pengaruh Media Pembelajaran...

meningkatkan kemampuan peserta literature), serta merumuskan didik dalam memahami materi kontribusi teoritis dan metodologinya pembelajaran dan layak atau dapat digunakan untuk proses pembelajaran.

Berdasarkan latar belakang yang diuraikan diatas maka penelitian ini bertujuan untuk mengetahui pengaruh media pembelajaran berbasis video untuk meningkatkan pemahaman siswa pada konsep fisika.

\section{METODE}

Pada penelitian ini kami menggunakan metode penelitian yang berupa studi kepustakaan (library research), yaitu serangkaian penelitian yang berkenaan dengan metode pengumpulan data pustaka, atau penelitiannya dikumpulkan melalui berbagai macam informasi kepustakaan (jurnal ilmiah, buku, ensiklopedia, majalah, koran, dan dokumen). Penelitian kepustakaan atau kajian literatur (literature review, literature research) merupakan penelitian yang mengkaji atau meninjau secara kritis pengetahuan, gagasan, atau temuan yang terdapat di dalam tubuh literatur berorientasi akademik (academic-oriented untuk topik tertentu (Farisi, 2012).

Penelitian kepustakaan difokuskan beberapa hal yaitu menemukan berbagai macam teori, hukum, prinsip, atau gagasan yang digunakan untuk menganalisis penelitian yang di lakukan, contohnya seperti mencari literatur-literatur yang membahas tentang pengaruh media pembelajaran berbasis video untuk meningkatkan pemahaman siswa pada konsep fisika. Studi kepustakaan juga dapat mempelajari berbagai buku referensi serta hasil penelitian sebelumnya yang sejenisnya yang berguna untuk mendapatkan landasan teori mengenai masalah yang akan diteliti. Penelitian ini bersifat kualitatif yang lebih mengutamakan penggalian, penemuan, pembacaan, penjelasan dan penyampaian makna atau simbol data yang tersurat dan terserat dari data yang dikumpulkan. Studi kepustakaan juga berarti teknik pengumpulan data dengan melakukan penelaahan terhadap buku, literatur, catatan, serta berbagai laporan yang berkaitan dengan masalah yang ingin dipecahkan. Sedangkan menurut ahli 
Haidir., Farkha., Mulhayatiah. - Analisis Pengaruh Media Pembelajaran...

lain studi kepustakaan merupaakan kajian teoritis, referensi serta literatur ilmiah lainnya yang berkaitan dengan budaya, nilai dan norma yang berkembang pada situasi sosial yang diteliti (Mirzaqon \& Purwoko, 2017).

Adapun langkah-langkah dalam melakukan penelitian kepustakaan yaitu pemilihan topik, eksplorasi informasi, menentukan fokus penelitian, pengumpulan sumber data, persiapan penyajian data dan penyusunan laporan. Sumber data yang menjadi bahan akan penelitian ini berupa jurnal ilmiah, buku dan situs internet yang terkait dengan topik yang telah dipilih. Teknik pengumpulan data dalam penelitian ini adalah mencari data mengenai halhal atau variabel yang berupa jurnal ilmiah, buku, artikel dan sebagainya yang membahas tentang pengaruh media pembelajaran berbasis video untuk meningkatkan pemahaman siswa pada konsep fisika. Teknik analisis data yang digunakan dalam penelitian ini adalah metode analisis isi teori yang dikumpulkan (content analysis). Analisis ini digunakan untuk mendapatkan inferensi yang valid dan dapat diteliti ulang berdasarkan konteksnya. Dalam analisis ini akan dilakuakan proses memilih, membandingkan, menggabungkan dan memilih berbagai pengertian hingga ditemukan yang relevan. Untuk menjaga proses pengkajian dan mencegah serta mengatasi mis-informasi (kesalahan pengertian manusiawi yang bisa terjadi karena kekurangan penulis pustaka) maka dilakukan pengecekan antar pustaka dan memperhatikan komentar pembimbing (Mirzaqon \& Purwoko, 2017).

\section{HASIL DAN PEMBAHASAN}

Media Pembelajaran Berbasis

Video

Media pembelajaran adalah seluruh alat dan bahan yang dapat dipakai untuk mencapai tujuan pendidikan seperti radio, televisi, buku koran, majalah dan sebagainya. Selain itu, ada beberapa alasan berkenaan dengan pemanfaatan media pembelajaran, diantaranya; pelajaran akan lebih menarik perhatian siswa, bahan pelajaran akan lebih mudah dipelajari oleh siswa, metode mengajar akan lebih bervariasi, dan siswa akan lebih banyak aktif dalam 
Haidir., Farkha., Mulhayatiah. - Analisis Pengaruh Media Pembelajaran...

proses kegiatan belajar bahkan yang lebih efektif yaitu menggunakan penggunaan media akan dapat media pembelajaran berbasis video. mempertinggi kualitas proses dan Hal ini berarti masih ada media hasil pengajaran (Sakti, 2019).

Adapun yang dibahas pada artikel ini yaitu hasil analisis dari beberapa arttikel mengenai media pembelajaran berbasis video.Latar belakang dari artikel yang dianalisis terkait dengan bagaimana meningkatkan hasil pembelajaran peserta didik dengan pembelajaran yang kurang efektif untuk meningkatkan hasil belajar peserta didik. Pada tabel 1 disajikan hasil analisis beberapa artikel yang menyebabkan hasil belajar kurang effektif dan mengusulkan menggunakan media pembelajaran berbasis video. menggunakan media pembelajaran

Tabel 1. Analisis Media Pembelajaran

\begin{tabular}{|c|c|c|}
\hline No & Media Pembelajaran & Hasil Belajar \\
\hline 1 & Power Point & $\begin{array}{l}\text { Kurang Efektif dan masih banyak peserta } \\
\text { didik mendapatkan hasil belajar yang kurang } \\
\text { dari KKM }\end{array}$ \\
\hline 2 & Ceramah & $\begin{array}{l}\text { Peserta didik merasa jenuh dengan } \\
\text { menggunakan media pembelajaran metode } \\
\text { ceramah }\end{array}$ \\
\hline 3 & Papan Tulis & $\begin{array}{l}\text { Kurang efektif dan peserta didik merasa } \\
\text { bosan dengan media papan tulis dan } \\
\text { menyebabkan keatktifan peserta didik kurang }\end{array}$ \\
\hline 4 & Buku & $\begin{array}{l}\text { Media pembelajaran dengan menggunakan } \\
\text { media buku bisa menyebabkan hasil belajar } \\
\text { peserta didk yang kurang }\end{array}$ \\
\hline
\end{tabular}

Hasil dari beberapa artikel dengan penulis (Agustiningsih, 2015), (Fauzan \& Rahdiyanta, 2017) (Yunita \& Wijayanti, 2017), (Busyaeri, Udin, \& Zaenuddin, 2016), (Sakti, 2019), (Yudha, Asrul, \&
Kamus, 2016), (Basri \& Khatimah, 2019), (Jannah, Harijanto, \& Yushardi, 2019), (Fatwani, Karmin, \& Sulistiwati, 2018), (Aththibby, Widodo, \& Mundilarto, 2021), (Alidrus, Hikmawati, \& Wahyudi, 2015), 
Haidir., Farkha., Mulhayatiah. - Analisis Pengaruh Media Pembelajaran...

(Diani, Yuberti, \& Syafitri, 2016), 2015) yang kami analisis dapat dilihat dan (Johari, Hasan, \& Rakhman, pada tabel 2.

Tabel 2. Hasil Analisis Artikel

\begin{tabular}{ccl}
\hline No & Aspek & \multicolumn{1}{c}{ Hasil } \\
\hline 1 & Hasil Belajar & Media pembelajaran berbasis \\
& & video mampu meningkatkan \\
& hasil belajar peserta didik \\
& & Media pembelajaran berbasis \\
& & video dapat meningkatkan \\
& & aspek kognitif dan aspek \\
& & psikomotor pada peserta didik \\
\hline 2 & Kepraktisan & Media pembelajaran berbasis \\
& & video lebih praktis dalam \\
& & pembelajaran fisika baik \\
& & disekolah maupun dirumah \\
\hline 3 & Minat dan Motivasi & Media pembelajaran berbasis \\
& & video sangat diminati peserta \\
& & didik. \\
\hline 4 & Pencapaian Tujuan & Media pembelajaran berbasis \\
& & video mampu menjadi media \\
& & alternatif guru sebagai alat \\
& & untuk mendukung ketercapaian \\
& & penerapan Kurikulum 2013. \\
\hline
\end{tabular}

Kelebihan dari media pembelajaran berbasis video dari beberapa artikel yang sudah dianalisis adalah: Media pembelajaran video sangat berpengaruh dalam hasil belajar peserta didik. Sedangkan kekurangan dari media pembelajaran berbasis video adalah diperlukan kreatifitas yang tinggi untuk menciptakan media pembelajaran berbasis video yang menarik minat peserta didik. Hal ini mensyaratkan guru harus mampu mengusai teknologi yang terus berkembang.

\section{KESIMPULAN DAN SARAN}

\section{Kesimpulan}

Berdasarkan dari berbagai hasil studi kepustakaan (library research) dapat disimpulkan bahwa:

Media pembelajaran berbasis video sangat layak digunakan dalam proses pembelajaran dan media pembelajaran berbasis video juga sangat diminati peserta didik. 
Haidir., Farkha., Mulhayatiah. - Analisis Pengaruh Media Pembelajaran...

Media pembelajaran berbasis

video dapat mempengaruhi aktifitas pembelajaran peserta didik.

\section{Saran}

Berdasarkan kesimpulan, maka terdapat peluang untuk mengembangkan media pembelajaran berbasis video untuk meningkatkan pemahaman siswa pada konsep fisika.

\section{DAFTAR PUSTAKA}

Agustiningsih, A. (2015). Video Sebagai Alternatif Media Pembelajaran Dalam Rangka Mendukung Keberhasilan Penerapan Kurikulum 2013 di Sekolah Dasar. PEDAGOGIA: Jurnal Pendidikan, 4(1), 50-58.

Al-idrus, S. Q. M. J., Hikmawati, H., \& Wahyudi, W. (2015). Pengaruh model pembelajaran berbasis masalah berbantuan video kartun terhadap hasil belajar fisika siswa kelas xi sman 1 sikur tahun ajaran 2014/2015. Jurnal Pijar MIPA, 10(1).

Aththibby, A. R. (2021, February). Animation-based Learning Effectiveness in Physics Learning. In Journal of Physics: Conference Series (Vol. 1779, No. 1, p. 012046). IOP Publishing.

Basri, S., \& Khatimah, H. (2019). Efektivitas Penggunaan Media Pembelajaran Sparkol Videoscribe Terhadap Hasil Belajar Fisika Peserta Didik

$\begin{array}{lrr}\text { Kelas XI } & \text { SMA Negeri } 6 \\ \text { Jeneponto. } & \text { Karst: } & \text { jurnal } \\ \text { pendidikan } & \text { fisika } & \text { dan } \\ \text { terapannya, 2(2), 85-90. } & \end{array}$

Busyaeri, A., Udin, T., \& Zaenudin, A. (2016). Pengaruh penggunaan video pembelajaran terhadap peningkatan hasil belajar mapel IPA di MIN Kroya Cirebon. Al Ibtida: Jurnal Pendidikan Guru MI, 3(1).

Diani, R., Yuberti, Y., \& Syafitri, S. (2016). Uji Effect Size Model Pembelajaran Scramble dengan Media Video terhadap Hasil Belajar Fisika Peserta Didik Kelas X MAN 1 Pesisir Barat. Jurnal Ilmiah Pendidikan Fisika Al-Biruni, 5(2), 265-275.

Farisi, M. I. (2012). Pengembangan Asesmen Diri Siswa (Student Self-Assessment) sebagai Model Penilaian dan Pengembangan Karakter. Artikel disampaikan pada Konferensi Ilmiah Nasional "Asesmen dan Pembangunan Karakter Bangsa” HEPI UNESA.

Fatmawati, E., Karmin, K., \& Sulistiyawati, R. S. (2018). Pengaruh Media Pembelajaran Berbasis Video Terhadap Hasil Belajar Siswa. Cakrawala: Jurnal Pendidikan, 12(1), 24-31.

Fauzan, M. A., \& Rahdiyanta, D. (2017). Pengembangan media pembelajaran berbasis video pada teori pemesinan Frais. Jurnal Dinamika Vokasional Teknik Mesin, 2(2), 82-88.

Jannah, M., Harijanto, A., \& Yushardi, Y. (2019). Aplikasi Media Pembelajaran Fisika 
Haidir., Farkha., Mulhayatiah. - Analisis Pengaruh Media Pembelajaran...

Berbasis Sparkol Videoscribe Pada Pokok Bahasan Suhu Dan Kalor Terhadap Hasil Belajar Siswa SMK. Jurnal Pembelajaran Fisika, 8(2), 6572.

Johari, A., Hasan, S., \& Rakhman, M. (2015). Penerapan Media Video Dan Anaimasi Pada Materi Memvakum Dan Mengisi Refrigeran Terhadap Hasil Belajar Siswa. Journal of Mechanical Engineering Education, 1 (1), 8-15.

Hafizah, S. (2020). Penggunaan dan Pengembangan Video dalam Pembelajaran Fisika. Jurnal Pendidikan Fisika, 8(2), 225-240.

Mirzaqon T, A., \& Purwoko, B. (2017). Studi Kepustakaan Mengenai Landasan Teori dan Praktik Konseling Expressive Writing. Jurnal BK Unesa, 8(1).
Sakti, I. (2019). Pengaruh Penggunaan Media Pembelajaran Berbasis Videoscribe Terhadap Pemahaman Konsep Fisika Siswa SMP Ittihad Makassar. PHYDAGOGIC Jurnal Fisika dan Pembelajarannya, 1(2), 4954 .

Yudha, S. F. A., Asrul, A., \& Kamus, Z. (2016). Pembuatan bahan ajar fisika berbasis video menggunakan sparkol videoscribe untuk pembelajaran fisika siswa kelas x SMA. Pillar of Physics Education, 8(1).

Yunita, D., \& Wijayanti, A. (2017). Pengaruh Media Video Pembelajaran Terhadap Hasil Belajar IPA Ditinjau Dari Keaktifan Siswa. Sosiohumaniora: Jurnal Ilmiah Ilmu Sosial Dan Humaniora, $3(2)$. 